\title{
The role of different soil sample digestion methods on trace elements analysis: a comparison of ICP-MS and INAA measurement results
}

\author{
Stefania Gaudino - Chiara Galas • Maria Belli • \\ Sabrina Barbizzi • Paolo de Zorzi • Radojko Jaćimović • \\ Zvonka Jeran · Alessandra Pati · Umberto Sansone
}

Received: 30 January 2006 / Accepted: 6 December 2006 / Published online: 18 January 2007

(C) Springer-Verlag 2007

\begin{abstract}
The measurement of trace-element concentration in soil, sediment and waste, is generally a combination of a digestion procedure for dissolution of elements and a subsequent measurement of the dissolved elements. "Partial" and "total" digestion methods can be used in environmental monitoring activities. To compare measurement results obtained by different methods, it is crucial to determine and to maintain control of the bias of the results obtained by these methods. In this paper, ICP-MS results obtained after matrix digestion with modified aqua regia $\left(\mathrm{HCl}+\mathrm{HNO}_{3}+\mathrm{H}_{2} \mathrm{O}_{2}\right)$ method and two "total" digestion methods (microwave aqua regia $+\mathrm{HF}$ and $\mathrm{HNO}_{3}+\mathrm{HF}$ ) are compared with those obtained by instrumental neutron activation analysis, a nondestructive analytical method for the determination of the total mass concentrations of inorganic components in environmental matrices. The comparison was carried out on eight agricultural soil samples collected in one test area and measured by $\mathrm{k}_{0}$-INAA and ICP-MS to determine $\mathrm{As}, \mathrm{Co}, \mathrm{Cr}$, $\mathrm{Sb}$ and $\mathrm{Zn}$ mass concentration. The bias of results for $\mathrm{As}, \mathrm{Cd}$, $\mathrm{Co}, \mathrm{Cr}, \mathrm{Cu}, \mathrm{Ni}, \mathrm{Pb}, \mathrm{Sb}$ and $\mathrm{Zn}$ of the three digestion methods were assessed using selected measurement standards. This
\end{abstract}

S. Gaudino · C. Galas · M. Belli · S. Barbizzi · P. de Zorzi · A. Pati

Agenzia per la Protezione dell'Ambiente e per i Servizi Tecnici

(APAT), Servizio Laboratori, Misure ed Attività di Campo,

Via di Castel Romano,

100-00128 Rome, Italy

R. Jaćimović · Z. Jeran

Jožef Stefan Institute,

Jamova 39,

1000 Ljubljana, Slovenia

U. Sansone $(\bowtie)$

International Atomic Energy Agency (IAEA),

Agency's Laboratories Seibersdorf,

1400 Vienna, Austria

e-mail: u.sansone@iaea.org paper highlights that the digestion procedure is an integral part of the measurement and can affect the measurement result in environmental analysis.

Keywords Digestion methods · Trace elements · Soils · INAA $\cdot$ ICP-MS

\section{Introduction}

Measurement of trace-element mass concentrations in soils is the first step in evaluating their potential health or ecological hazard. Sample digestion is often a necessary step before determining "total" element mass concentrations in soils. A standard and relatively safe dissolution method that provides an analytical recovery of at least approximately $90 \%$ of soil bound elements is required in most laboratories working on trace elements in soil.

Various digestion methods are used to determine the mass concentration of trace elements in solid matrices, including different combinations of concentrated acids [1-3]. Open beakers heated on hot plates, digestion tubes in a block digester, and digestion bombs placed in microwave ovens are the most commonly used equipment to digest solid sample matrices.

In particular, since the 1980 s, the microwave-assisted sample digestion technique has become popular and presently it is widely used due to its safe, rapid and efficient performance [4-6].

Since different acid digestion methods applied to soil samples can release a different amount of elements from this matrix, it is critical to compare different digestion methods used to determine elemental mass fractions in soils. As reported by Chen and Lena [4], the amount of trace element extracted by the commonly used digestion 
methods might depend on the element, their origin (anthropogenic or natural), soil properties and element mass fractions.

The aqua regia digestion method (USEPA 3050 [7] or ISO standard 11466 [8]) is considered effective for measuring "total" trace element in soils and is usually used to give an estimate of the maximum element availability to plants $[4,9]$. This method consists of treating a soil sample with a 3:1 mixture of hydrochloric $(\mathrm{HCl})$ and nitric $\left(\mathrm{HNO}_{3}\right)$ acids. The nitric acid destroys organic matter and oxidizes sulphide material. It reacts with concentrated hydrochloric acid to generate aqua regia: $3 \mathrm{HCl}+\mathrm{HNO}_{3} \rightarrow 2 \mathrm{H}_{2} \mathrm{O}+\mathrm{NOCl}+\mathrm{Cl}_{2}$. Aqua regia is considered adequate for dissolving most base element sulphates, sulphides, oxides and carbonates but only provides a "partial" extraction for most rock forming elements and elements of a refractory nature. For example, aqua regia extraction might give complete recovery for $\mathrm{Cd}$, $\mathrm{Cu}, \mathrm{Pb}$ and $\mathrm{Zn}$ while it is known to provide partial recovery for $\mathrm{Cr}, \mathrm{Ni}$ and $\mathrm{Ba}$. The latter elements can only be efficiently recovered by using hydrofluoric acid (HF). However, aqua regia digestion method is internationally accepted to measure concentrations in soil, admitting that the fraction of elements not extracted by this method, as not available for biological uptake. The ISO standard on aqua regia digestion of soil includes only digestion by the use of hot plate heating, while the modified aqua regia digestion method, suggested by the Italian legislation, includes both hot-plate heating and microwave-oven heating [10]. The aqua regia modified method adds, in the first step, hydrogen peroxide $\left(\mathrm{H}_{2} \mathrm{O}_{2}\right)$ in order to enhance the destruction of the organic matter in the soil.

More vigorous $\mathrm{HNO}_{3}+\mathrm{HCl}+\mathrm{HF}$ digestion methods (like EN 13656 applied to wastes [11]) provide satisfactory dissolution of silica matrices [12-15]. These methods use microwave-assisted acid digestion for "total" sample decomposition and are applicable to up to 30 elements. $\mathrm{HNO}_{3}+\mathrm{HCl}+\mathrm{HF}$ and $\mathrm{HNO}_{3}+\mathrm{HF}$ mixtures dissolve silica matrices due to the presence of $\mathrm{HF}$, via the reaction: $\mathrm{HF}+\mathrm{SiO}_{2} \rightarrow \mathrm{H}_{2} \mathrm{SiF}_{6}+\mathrm{H}_{2} \mathrm{O}$.

In the present study, the three digestion methods reported above were compared for the analysis of eight agricultural soil samples collected at an Italian reference site, previously characterized within the framework of an APAT project focused on soil sampling uncertainty evaluation [16, 17]. The measurand elements (As, $\mathrm{Cd}, \mathrm{Co}, \mathrm{Cr}, \mathrm{Cu}, \mathrm{Ni}, \mathrm{Pb}, \mathrm{Sb}$ and $\mathrm{Zn}$ ) were measured in the solutions of digested samples using inductively coupled plasma mass spectrometer (ICPMS). Furthermore, five elements (As, Co, Cr, Sb, Zn) were measured by the $\mathrm{k}_{0}$-standardization method of Instrumental Neutron Activation Analysis ( $\mathrm{k}_{0}$-INAA). INAA is a nondestructive analytical method for the measurement of inorganic components in solid matrices, because this method does not require any sample dissolution. INAA is a valu- able technique particularly for elements that form or are in refractory phases that may be difficult to dissolve [18]. In this way, the effect of the dissolution step on the final measurement results for $\mathrm{As}, \mathrm{Co}, \mathrm{Cr}, \mathrm{Sb}$ and $\mathrm{Zn}$ was investigated.

The difference between the reference values and the ICP-MS results on the solutions obtained in the laboratory with the three different digestion procedures was evaluated by the laboratory bias. The modified microwave aqua regia method was applied to two different certified reference materials (LGC-6187 and BCR-141R) characterized for hot aqua regia total-recoverable trace elements. The microwave aqua regia $+\mathrm{HF}$ and $\mathrm{HNO}_{3}+\mathrm{HF}$ methods were applied to digest two IAEA reference materials (SL1 and Soil-7) characterized for total elements. IAEA Soil7 was as well used as quality control material for INAA measurements.

\section{Materials and methods}

Sample collection

Eight soil samples were collected at an agricultural site, located in the North East of Italy (Pozzuolo del Friuli, Udine), within the framework of an APAT project [16]. Sampling was performed in June 2001, using strictly controlled protocols. The details of sampling are fully described in Barbizzi et al. [17]. The agricultural area sampled reveals a quite balanced soil grain size distribution with a slight dominance of the silt fraction $(47 \%)$ and a low percentage of clay (below $16 \%$ ). On average, the fraction above $2 \mathrm{~mm}$ represents only the $13 \%$ of the sampled soil. Relatively high $\mathrm{pH}$ values (about 7.7) and a low percentage of organic carbon content are observed. The cation exchange capacity (CEC) along the area, reveals low values (in average below $16 \mathrm{cmol}_{(+)} \mathrm{kg}^{-1}$ ). These are compatible both with the slight contribution derived by low clay content and the poor level of organic carbon.

\section{Sample preparation}

Soil samples were weighed and stored in cardboard boxes and then dried in an oven with a fan at $36-40^{\circ} \mathrm{C}$ until constant weight was reached. Then they were disaggregated using a wood pestle, sieved at $2 \mathrm{~mm}$, the volume was reduced by quartering and riffling and at the end the laboratory samples were milled at $90 \mu \mathrm{m}$ to obtain the test samples [19]. Barbizzi et al. [17] report in more detail the sample preparation steps. From each of the eight test samples, nine test portions [19] were taken for trace metals analysis by ICP-MS and 1 test portion was taken for INAA analysis. The homogeneity of the test samples has been tested by INAA, analyzing ten test portions from three different test samples. 
Table 1 Microwave oven digestion cycles (methods A-B-C)

\begin{tabular}{|c|c|c|c|c|c|}
\hline \multicolumn{2}{|c|}{ Method $\mathrm{A} \mathrm{HNO}_{3}+\mathrm{HF}$} & \multicolumn{2}{|c|}{ Method $\mathrm{B} \mathrm{HCl}+\mathrm{HNO}_{3}+\mathrm{HF}$} & \multicolumn{2}{|c|}{ Method $\mathrm{CHCl}+\mathrm{HNO}_{3}+\mathrm{H}_{2} \mathrm{O}_{2}$} \\
\hline Time (min) & Power $(\mathrm{W})$ & Time (min) & Power $(\mathrm{W})$ & Time (min) & Power (W) \\
\hline 10 & 250 & 2 & 500 & 10 & 250 \\
\hline 10 & 400 & 2 & 0 & 10 & 450 \\
\hline 10 & 650 & 5 & 500 & 10 & 600 \\
\hline 5 & 400 & 5 & 800 & 5 & 250 \\
\hline 10 & 250 & 5 & 1,000 & & \\
\hline
\end{tabular}

\section{Digestion methods}

Microwave digestions were performed in a close microwave oven system (CEM Corporation Mars 5, Matthews, NC, USA).

For the three digestion methods, a test portion of about $0.1 \mathrm{~g}$ was weighed into a $120-\mathrm{mL}$ Teflon-PFA microwave digestion vessel after manually shaking the bottles for at least 1 min. The $\mathrm{HNO}_{3}+\mathrm{HF}$ digestion (method A) was performed by adding to the soil a mixture of $3 \mathrm{~mL}$ of $\mathrm{HNO}_{3}$ and $2 \mathrm{~mL}$ of $\mathrm{HF}$.

The aqua regia + HF digestion (method $B)$ used in the present work followed the EN 13656 method [11] developed for elemental measurement in wastes. A freshly prepared mixture of $2 \mathrm{~mL} \mathrm{HNO} 3+6 \mathrm{~mL} \mathrm{HCl}+2 \mathrm{~mL} \mathrm{HF}$ was added to the sample.

The modified aqua regia digestion followed the method suggested by the Italian legislation (method C) [10]. First $1.5 \mathrm{~mL} \mathrm{H}_{2} \mathrm{O}_{2}, 4.5 \mathrm{~mL} \mathrm{HCl}$ and $1.5 \mathrm{~mL} \mathrm{HNO}_{3}$ were added to the soil. Hydrogen peroxide was used to enhance the destruction of organic matter.

All the samples were microwave digested following the digestion cycles reported in Table 1. The time integrated energy was 5,265 and 3,192 kJ, respectively, for methods $\mathrm{A}$ and B. Each digestion cycle was performed using the maximum number of vessels available (12 vessels).

The three digestion procedures were performed in triplicate for each test sample (CRMs, RMs and agricultural soil samples).

After digestion, each aliquot was quantitatively transferred to a volumetric flask (Brand) and diluted with MilliQ water to $100 \mathrm{~mL}$. Before diluting, rhodium at a concentration of $10 \mu \mathrm{g} / \mathrm{L}$ was added as internal standard to minimize the instrumental signal fluctuation and matrix effects. The solutions were allowed to stand for $24 \mathrm{~h}$ without removing the undissolved residue and then analyzed by ICP-MS.

Nitric acid, hydrofluoric acid and hydrochloric acid of ultra-pure grade were purchased from Merck.

\section{ICP-MS measurements}

Trace metal mass fractions were measured on an Agilent technologies 7500c ICP-MS equipped with a collision cell to minimize polyatomic interferences and matrix effects.
Babington nebulizer, standard spray chamber, Cetac ASX 500 auto sampler was used in the measurements. The collision cell was pressurized with He gas (flow of $2.9 \mathrm{~mL} \mathrm{~min}^{-1}$ ) to reduce interferences by dissociating interfering polyatomic species by collision and by charge transfer. The ICPMS is optimized daily with a tuning solution at $10 \mu \mathrm{g} \mathrm{L}^{-1}$ of $\mathrm{Li}, \mathrm{Ce}, \mathrm{Y}, \mathrm{Tl}$. Optimization is performed using normal mode and collision cell mode. A typical analytical run after optimization of the ICP-MS consists of calibration standard solutions, procedure blanks, samples and CRM. Calibration standard solutions are daily prepared from a working standard solution containing $5 \mu \mathrm{g} \mathrm{mL}^{-1}$ of $\mathrm{Cr}$ and $\mathrm{Zn}, 0.5 \mu \mathrm{g} \mathrm{mL}^{-1}$ of $\mathrm{Co}, 1.5 \mu \mathrm{g} \mathrm{mL}^{-1}$ of $\mathrm{Ni}$ and $\mathrm{Cu}, 0.1 \mu \mathrm{g} \mathrm{mL}^{-1}$ of $\mathrm{Cd}$ and $\mathrm{Sb}$ and $2.5 \mu \mathrm{g} \mathrm{mL}^{-1}$ of $\mathrm{Pb}$. The working standard solution was prepared from $1,000 \mu \mathrm{g} \mathrm{mL}^{-1}$ stock solutions of all elements by dilution with ultra-pure water in a $100-\mathrm{mL}$ volumetric flask. Calibration curve has been determined on five points for each element, in a range from 0 to $300 \mathrm{ng} \mathrm{mL}^{-1}$ for $\mathrm{Cr}$ and $\mathrm{Zn}, 0$ to $30 \mathrm{ng} \mathrm{mL}^{-1}$ for Co, 0 to $90 \mathrm{ng} \mathrm{mL}^{-1}$ for $\mathrm{Ni}$ and $\mathrm{Cu}, 0$ to $6 \mathrm{ng} \mathrm{mL}^{-1}$ for $\mathrm{Cd}$ and $\mathrm{Sb}$ and 0 to $150 \mathrm{ng} \mathrm{mL}^{-1}$ for $\mathrm{Pb}$. The calibration standard solutions are traceable to values embodied in measurement standards issued by the NIST.

The ${ }^{75} \mathrm{As},{ }^{59} \mathrm{Co},{ }^{52} \mathrm{Cr},{ }^{60} \mathrm{Ni},{ }^{63} \mathrm{Cu},{ }^{66} \mathrm{Zn},{ }^{111} \mathrm{Cd},{ }^{121} \mathrm{Sb}$ and ${ }^{208} \mathrm{~Pb}$ isotopes were chosen for measurement. In the present work, He gas was demonstrated to effectively minimize the interferences of ${ }^{40} \mathrm{Ar}{ }^{35} \mathrm{Cl}$ on the isotope ${ }^{75} \mathrm{As},{ }^{40} \mathrm{Ar}{ }^{12} \mathrm{C}$ on ${ }^{52} \mathrm{Cr},{ }^{40} \mathrm{Ar}{ }^{18} \mathrm{O}$ on the isotope ${ }^{59} \mathrm{Co}$ and ${ }^{44} \mathrm{Ca}{ }^{16} \mathrm{O},{ }^{23} \mathrm{Na}{ }^{37} \mathrm{Cl}$ on the isotope ${ }^{60} \mathrm{Ni}$. For the agricultural soils the collision cell was used only for ${ }^{59} \mathrm{Co}$ and ${ }^{75} \mathrm{As}$. Two procedure blanks and two RMs were measured every eight samples.

\section{$k_{0}$ - INAA measurements}

Measurement of As, $\mathrm{Co}, \mathrm{Cr}, \mathrm{Sb}$ and $\mathrm{Zn}$ by $\mathrm{k}_{0}$-INAA were carried out at the Jožef Stefan Institute, Ljubljana, Slovenia. For details about $\mathrm{k}_{0}$-INAA and the relevant nuclear data see Jaćimović et al. [18].

Test portions of about $0.2 \mathrm{~g}$ (one for each test sample) were sealed into suprapure plastic containers and irradiated for about $20 \mathrm{~h}$ in the carousel facility of the TRIGA Mark II reactor, Ljubljana (thermal neutron flux $1.0 \times 1,012 \mathrm{n} \mathrm{cm}^{-2} \mathrm{~s}^{-1}$ ). A $1.0-\mathrm{mm}$ Al-0.1\% Au alloy wire pressed into a disk (diameter of $6 \mathrm{~mm}$, thickness $0.2 \mathrm{~mm}$ ) was co-irradiated with the 
Table 2 Element mass fractions measured by INAA in the RM IAEA Soil-7

\begin{tabular}{lll}
\hline $\begin{array}{l}\text { IAEA } \\
\text { Soil-7 }\end{array}$ & $\begin{array}{l}\text { Recommended value }(95 \% \\
\text { confidence interval })\left(\mathrm{mg} \mathrm{kg}^{-1}\right)\end{array}$ & $\begin{array}{l}\text { INAA }(n=14) \\
\left(\mathrm{mg} \mathrm{kg}^{-1}\right)\end{array}$ \\
\hline $\mathrm{Cr}$ & $60(49-74)$ & $69.5 \pm 5.2$ \\
$\mathrm{Co}$ & $8.9(8.4-10.1)$ & $8.8 \pm 0.6$ \\
$\mathrm{Zn}$ & $104(101-113)$ & $103.1 \pm 6.2$ \\
$\mathrm{As}$ & $13.4(12.5-14.2)$ & $14.5 \pm 0.6$ \\
$\mathrm{Sb}$ & $1.7(1.4-1.8)$ & $1.8 \pm 0.09$ \\
\hline
\end{tabular}

Note: Results are reported with their standard deviations at an approximate level of $95 \%$. The table also reports the recommended values and the 95\% confidence intervals for IAEA Soil-7 $(n=$ number of independent replicates).

sample as a comparator. The irradiated samples were subsequently transferred to clean polyethylene vials and counted on calibrated coaxial HPGe detectors connected to a multichannel analyzer (MCA). Each irradiated sample was measured three times: after 2-3, 8, and 30 days cooling time. $\mathrm{k}_{0}$-INAA quality control was performed by using the measurement standard IAEA Soil-7. Results of quality control tests are reported in Table 2.

\section{Laboratory bias determination}

Measurement standards (RMs) such as IAEA SL-1 (lake sediment) and IAEA Soil-7 from the International Atomic Energy Agency (IAEA), Austria, and measurement standards (CRMs) BCR-141R (calcareous loam soil) from the European Commission, Belgium and LGC-6187 (river sediment) from the Laboratory of the Government Chemist (LGC), UK, were digested in triplicate following the procedures reported above. As previously stated, IAEA SL-1 and IAEA Soil-7 are characterized for total elements mass fractions and were processed using microwave aqua regia $+\mathrm{HF}$ and $\mathrm{HNO}_{3}+\mathrm{HF}$. The measurement standards BCR-141R and LGC-6187 are supplied with certified values for extractable elements using methods based on DIN 38414-S7 and ISO11466, respectively, and were digested in this study by using the modified aqua regia procedure. The BCR-141R is certified for total mass fraction as well. Bias was judged by comparing the measured mass fraction with the certified/recommended values of the measurement standards [14].

\section{Results presentation}

In this paper, the terms repeatability, standard deviation, etc., refer to ISO 3534-1 [20]. Repeatability was defined as the ratio of the standard deviation to the average, obtained under repeatability conditions, expressed as relative standard deviation. These standard deviations, associated with the measurement values for the measurands, are multiplied by a cov- erage factor of 2, to yield an approximate confidence level of $95 \%$.

Analytical recovery is defined as the value observed divided by the value expected and multiplied by 100 .

On the basis of the assumption that measurement results obtained on homogeneous material are distributed normally, the comparison between methods $(\mathrm{A}+\mathrm{B}+\mathrm{C}$ versus INAA and $\mathrm{A}+\mathrm{B}$ versus $\mathrm{C}$ ) was carried out using the grand mean, requiring data to be normally distributed. The assumption of normal distribution of the results is derived from interlaboratory comparisons carried out by APAT, in which the normality of the distribution of the element mass fraction in sediment/compost RMs was verified on data from about 70 laboratories [21, 22].

\section{Results and discussion}

Laboratory bias and repeatability standard deviations in RMs and CRMs

In general, recoveries ( $\% \mathrm{R})$ within 81 to $122 \%$ were obtained for all elements for the three digestion methods. Table 3 reports the results and associated standard deviations, obtained with methods A and B. A good agreement with the recommended values has been obtained for the Co, $\mathrm{Ni}, \mathrm{Cu}, \mathrm{As}, \mathrm{Sb}$ and $\mathrm{Cd}$ mass fractions for both methods in the two RMs (IAEA Soil-7 and IAEA SL-1).

Mass fraction low recoveries for $\mathrm{Cr}$ even using the $\mathrm{HF}$ (method A and B) are described in the literature [23, 24] and are associated with the presence of insoluble refractory $\mathrm{Cr}$ minerals such as chromospinels and chromites $\left(\mathrm{FeCr}_{2} \mathrm{O}_{7}\right)$. These minerals, frequently occurring in geological materials, are very difficult to dissolve and this behavior can result in low recovery. In this investigation, all values of "total" $\mathrm{Cr}$ mass fraction fall within the confidence intervals reported in the RM certificates. The lower efficiency of digestion methods in extracting $\mathrm{Cr}$ from soils can be detected aggregating by method the measurement results of the laboratories participating in the certification of IAEA Soil-7 and IAEA SL-1 $[25,26]$. The mean values obtained for IAEA Soil-7 are $67 \pm 6 \mathrm{mg} \mathrm{kg}^{-1}$, for measurements by direct INAA method, and $50 \pm 11 \mathrm{mg} \mathrm{kg}^{-1}$, for measurements by atomic absorption spectrometry. These values are respectively higher and lower than the recommended value. The same behavior is shown for IAEA SL-1 where the aggregated values lead to $112 \pm 19 \mathrm{mg} \mathrm{kg}^{-1}$ for INAA measurements, and $89 \pm 29 \mathrm{mg} \mathrm{kg}^{-1}$ for measurements obtained by atomic absorption spectrometry.

The $\mathrm{Zn}$ mass fraction values measured with method $\mathrm{A}$ in IAEA SL-1 is significantly lower than the reference value. In the other cases, measured $\mathrm{Zn}$ mass fraction values fall within the $95 \%$ confidence interval of the RMs, but all values are lower than the reference value. $\mathrm{Zn}$ is generally brought into 
Table 3 Element mass fractions for digestion methods A-B applied to IAEA Soil-7 and SL-1 RMs

\begin{tabular}{|c|c|c|c|c|c|c|}
\hline & & & Measured mass fract & & & \\
\hline & & & Method $\mathrm{A} \mathrm{HNO}_{3}+$ & & Method $\mathrm{B} \mathrm{HCl}+\mathrm{HN}$ & )$_{3}+\mathrm{HF}$ \\
\hline & IAEA Soil-7 & IAEA SL-1 & IAEA Soil-7 & IAEA SL-1 & IAEA Soil-7 & IAEA SL-1 \\
\hline & $\begin{array}{l}\text { Recommended value } \\
(95 \% \text { confidence } \\
\text { interval })\left(\mathrm{mg} \mathrm{kg}^{-1}\right)\end{array}$ & $\begin{array}{l}\text { Recommended value } \\
\text { (95\% confidence } \\
\text { interval) }\left(\mathrm{mg} \mathrm{kg}^{-1}\right)\end{array}$ & $(n=3)\left(\mathrm{mg} \mathrm{kg}^{-1}\right)$ & $(n=3)\left(\mathrm{mg} \mathrm{kg}^{-1}\right)$ & $(n=3)\left(\mathrm{mg} \mathrm{kg}^{-1}\right)$ & $(n=3)\left(\mathrm{mg} \mathrm{kg}^{-1}\right)$ \\
\hline $\mathrm{Cr}$ & $60(49-74)$ & $104 *(95-113)$ & $49 \pm 10$ & $109 \pm 19$ & $54 \pm 16$ & $106 \pm 17$ \\
\hline $\mathrm{Co}$ & $8.9(8.4-10.1)$ & $19.8(18.3-21.3)$ & $9 \pm 1$ & $18 \pm 3$ & $9 \pm 2$ & $18 \pm 4$ \\
\hline $\mathrm{Ni}$ & $26^{*}(21-37)$ & $44.9^{*}(36.9-53.9)$ & $26 \pm 3$ & $47 \pm 4$ & $25 \pm 9$ & $46 \pm 7$ \\
\hline $\mathrm{Cu}$ & $11(9-13)$ & $30 *(24-36)$ & $9.5 \pm 2$ & $30 \pm 4$ & $10 \pm 3$ & $30 \pm 6$ \\
\hline $\mathrm{Zn}$ & $104(101-113)$ & $223(213-233)$ & $94 \pm 13$ & $189 \pm 15$ & $90 \pm 22$ & $193 \pm 50$ \\
\hline As & $13.4(12.5-14.2)$ & $27.6(24.7-30.5)$ & $13.4 \pm 1.4$ & $28.2 \pm 1.5$ & $13 \pm 3$ & $28 \pm 5$ \\
\hline $\mathrm{Sb}$ & $1.7(1.4-1.8)$ & $1.31^{*}(1.19-1.43)$ & $1.7 \pm 0.2$ & $1.29 \pm 0.09$ & $1.6 \pm 0.4$ & $1.2 \pm 0.2$ \\
\hline $\mathrm{Cd}$ & $1.3^{*}(1.1-2.7)$ & $0.26^{*}(0.21-0.31)$ & $1.20 \pm 0.15$ & $0.26 \pm 0.03$ & $1.2 \pm 0.3$ & $0.21 \pm 0.09$ \\
\hline $\mathrm{Pb}$ & $60(55-71)$ & $37.7^{*}(30.3-45.1)$ & $49 \pm 7$ & $32 \pm 9$ & $60 \pm 14$ & $37 \pm 8$ \\
\hline
\end{tabular}

Note: Results are reported with their confidence level of $95 \%$. The table also reports the certified values and the 95\% confidence intervals for IAEA Soil-7 and SL-1 ( $n=$ number of independent replicates).

*Information value.

solution; hence the ICP-MS procedure used in this study needs further investigation.

The $\mathrm{Pb}$ mass fraction value measured by method $\mathrm{A}$ in IAEA Soil-7 is negatively biased. Low recoveries for $\mathrm{Pb}(81$ and $85 \%$ ) using method A may be related to the internal standard used. $\mathrm{Rh}$ is not suitable to minimize the instrumental signal fluctuation and matrix effects. The comparison between the results obtained with methods A and B shows that there is no a significant difference between the results obtained by these methods, with the exception of $\mathrm{Pb}$ in IAEA Soil-7. The results reported in Table 3 show that the standard deviations are generally lower for method A than in method B. This could be explained by the difference in total energy input used in the digestion steps. Method A uses a higher total energy input $(5,265 \mathrm{~kJ})$ than method B $(3,192 \mathrm{~kJ})$.
Table 4 reports the results obtained with method $\mathrm{C}$ in LGC-6187, certified for aqua regia method, and in BCR$141 \mathrm{R}$ certified for aqua regia extractable elements and for the total element mass fractions. The uncertainties reported for the CRMs represent the 95\% confidence limit. The standard deviations associated with the measured values are reported with an approximate level of confidence of $95 \%$. Generally, the repeatability for method C is lower for BCR-141R than for LGC-6187. This could be due to higher homogeneity of BCR-141R in comparison with that of the LGC-6187 certified reference material. The element mass fractions obtained on LGC-6187 were significantly higher for As, $\mathrm{Cr}$ and $\mathrm{Ni}$, while on BCR-141R only $\mathrm{Cr}$ and $\mathrm{Co}$ are positively biased in comparison with element mass fractions certified using aqua regia. For $\mathrm{Zn}, \mathrm{Cu}, \mathrm{Cd}$, and $\mathrm{Pb}$ the results with their standard deviation do not clearly overlap the $95 \%$ confidence

Table 4 Element mass fractions for digestion method C applied to LGC-6187 and BCR 141R CRMs

\begin{tabular}{|c|c|c|c|c|c|c|c|}
\hline & \multirow{2}{*}{$\begin{array}{l}\text { LGC6187 } \\
\text { Certificate aqua regia } \\
\text { soluble mass fraction } \\
\left(\mathrm{mg} \mathrm{kg}^{-1}\right)\end{array}$} & \multicolumn{2}{|l|}{ BCR 141R } & \multicolumn{4}{|c|}{$\frac{\text { Measured mass fractions }}{\text { Method } \mathrm{C} \mathrm{HCl}+\mathrm{HNO}_{3}+\mathrm{H}_{2} \mathrm{O}_{2}}$} \\
\hline & & $\begin{array}{l}\text { Certificate aqua regia } \\
\text { soluble mass fraction } \\
\left(\mathrm{mg} \mathrm{kg}^{-1}\right)\end{array}$ & $\begin{array}{l}\text { Certificate total mass } \\
\text { fraction }\left(\mathrm{mg} \mathrm{kg}^{-1}\right)\end{array}$ & $\begin{array}{l}\text { LGC6187 } \\
\left(\mathrm{mg} \mathrm{kg}^{-1}\right)\end{array}$ & $\begin{array}{l}(n=10), \mathrm{CV} \\
\%\end{array}$ & $\begin{array}{l}\text { BCR 141R } \\
\left(\mathrm{mg} \mathrm{kg}^{-1}\right)\end{array}$ & $\begin{array}{l}(n=4), \mathrm{CV} \\
\%\end{array}$ \\
\hline $\mathrm{Cr}$ & $84 \pm 9.4$ & $138 \pm 5$ & $195 \pm 7$ & $101 \pm 14$ & 6.8 & $155 \pm 7$ & 2.4 \\
\hline Co & & $9.2 \pm 0.5$ & $10.5 \pm 0.4$ & & & $10.1 \pm 0.1$ & 0.5 \\
\hline $\mathrm{Ni}$ & $34.7 \pm 1.7$ & $94 \pm 5$ & $103 \pm 3$ & $41 \pm 8$ & 9.3 & $93 \pm 8$ & 4.3 \\
\hline $\mathrm{Cu}$ & $83.6 \pm 4.1$ & $46.9 \pm 1.8$ & $46.4 \pm 1.8$ & $94 \pm 13$ & 6.8 & $46.4 \pm 0.2$ & 0.2 \\
\hline $\mathrm{Zn}$ & $439 \pm 26$ & $270 \pm 8$ & $283 \pm 5$ & $455 \pm 19$ & 2.1 & $261 \pm 6$ & 1.1 \\
\hline As & $24 \pm 3.2$ & & & $29 \pm 2$ & 3.1 & & \\
\hline $\mathrm{Cd}$ & $2.7 \pm 0.3$ & $14 \pm 0.4$ & $14.6 \pm 0.5$ & $2.9 \pm 0.4$ & 6.1 & $13.6 \pm 0.2$ & 0.6 \\
\hline $\mathrm{Pb}$ & $77.2 \pm 4.5$ & $51.3 \pm 2$ & $57.2 \pm 1.2$ & $82 \pm 4$ & 2.2 & $50.7 \pm 0.6$ & 0.6 \\
\hline
\end{tabular}

Note: Results are reported with their confidence level of $95 \%$. The table also reports the certified values for extractable metals, total mass fraction and their uncertainties. The uncertainty represents the half-width of the $95 \%$ confidence interval ( $n=$ number of independent replicates). 
interval of the recommended values. To check if the mass fraction values of these elements in LGC-6187 are biased, the criterion reported in ISO Guide 33 [27] has been used. On the basis of this criterion, that compares the bias with the uncertainty of the certified value combined with the standard deviation of the measurement process, $\mathrm{Zn}, \mathrm{Cu}, \mathrm{Cd}$ and $\mathrm{Pb}$ mass fractions are in good agreement with the certified values. The same ISO criterion was applied on the results obtained in BCR-141R. Zn mass fractions is in agreement in comparison with the certified value for aqua regia soluble mass fraction.

The comparison between the certified total element contents in BCR-141R and the values obtained with method C show that values for $\mathrm{Cr}$ and $\mathrm{Co}$ are negatively biased. The application of ISO criterion shows that measured $\mathrm{Zn}$ value is negatively biased.

The results reported above could be explained by the difference in measurement procedures used in this study, compared to those used for CRM certification. The degree of dissolution of solid sample with aqua regia depends on the input of energy. Method $\mathrm{C}$ uses a different power input and a different reaction time during the digestion step from those used in the certification of LGC-6187 (conventional heating under open reflux condition) and of BCR-141R. $\mathrm{H}_{2} \mathrm{O}_{2}$ used in method $\mathrm{C}$ enhances the dissolution of the organic mass fraction. To investigate the effects induced by the procedure used in this work, LGC-6187 was digested using microwave assisted aqua regia, without the addition of $\mathrm{H}_{2} \mathrm{O}_{2}$ (Table 5). In this case the mass fractions of $\mathrm{Cr}, \mathrm{Ni}, \mathrm{Cu}$ and $\mathrm{As}$ are in agreement with the certificate values, while the measured $\mathrm{Zn}$ mass fraction is negatively biased. This confirms the need of further investigation on the measurement of $\mathrm{Zn}$ by ICP-MS.

Comparison of the three digestion methods for measuring elements in agricultural soil samples

The homogeneity of the soil test samples was verified measuring by INAA 10 test portions from three different test

Table 5 Element mass fractions for assisted aqua regia digestion method applied to measurement of LGC-6187 CRM

\begin{tabular}{lll}
\hline & \multicolumn{2}{l}{ Method aqua regia (ISO11466*) } \\
\cline { 2 - 3 } & LGC6187 $\left(\mathrm{mg} \mathrm{kg}^{-1}\right)$ & $(n=3)$ Recovery \% \\
\hline $\mathrm{Cr}$ & $92 \pm 3$ & 110 \\
$\mathrm{Ni}$ & $36 \pm 2$ & 104 \\
$\mathrm{Cu}$ & $86 \pm 2$ & 103 \\
$\mathrm{Zn}$ & $390 \pm 56$ & 89 \\
$\mathrm{As}$ & $25.1 \pm 0.5$ & 105 \\
\hline
\end{tabular}

Note: Results are reported with their experimental standard deviations with a coverage factor of 2 to yield an approximate confidence level of 95\% ( $n=$ number of independent replicates).

*Microwave-assisted digestion method.

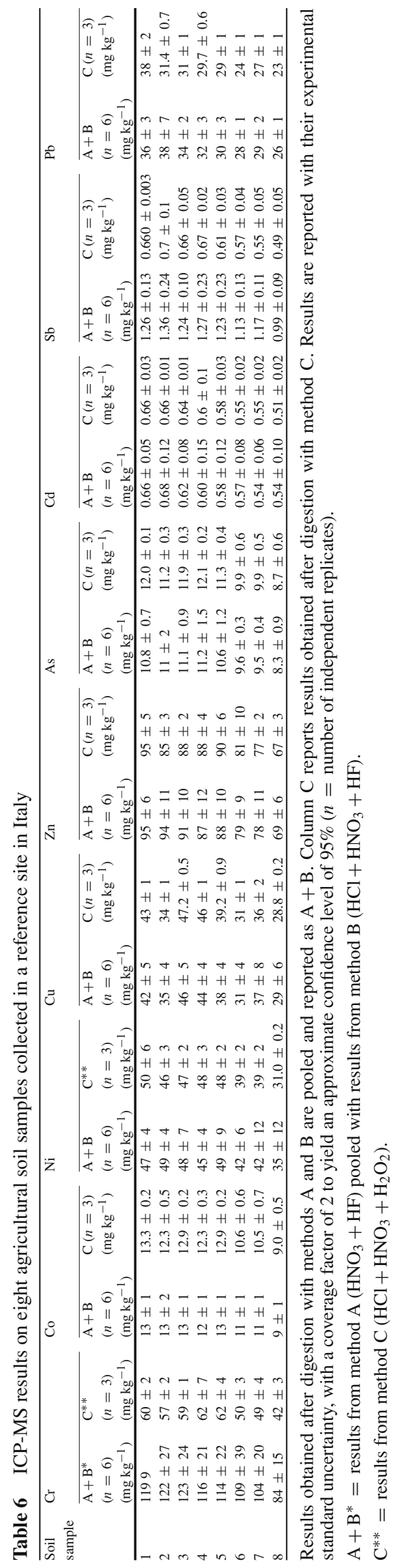




\section{Cr (Methods A-B-C)}

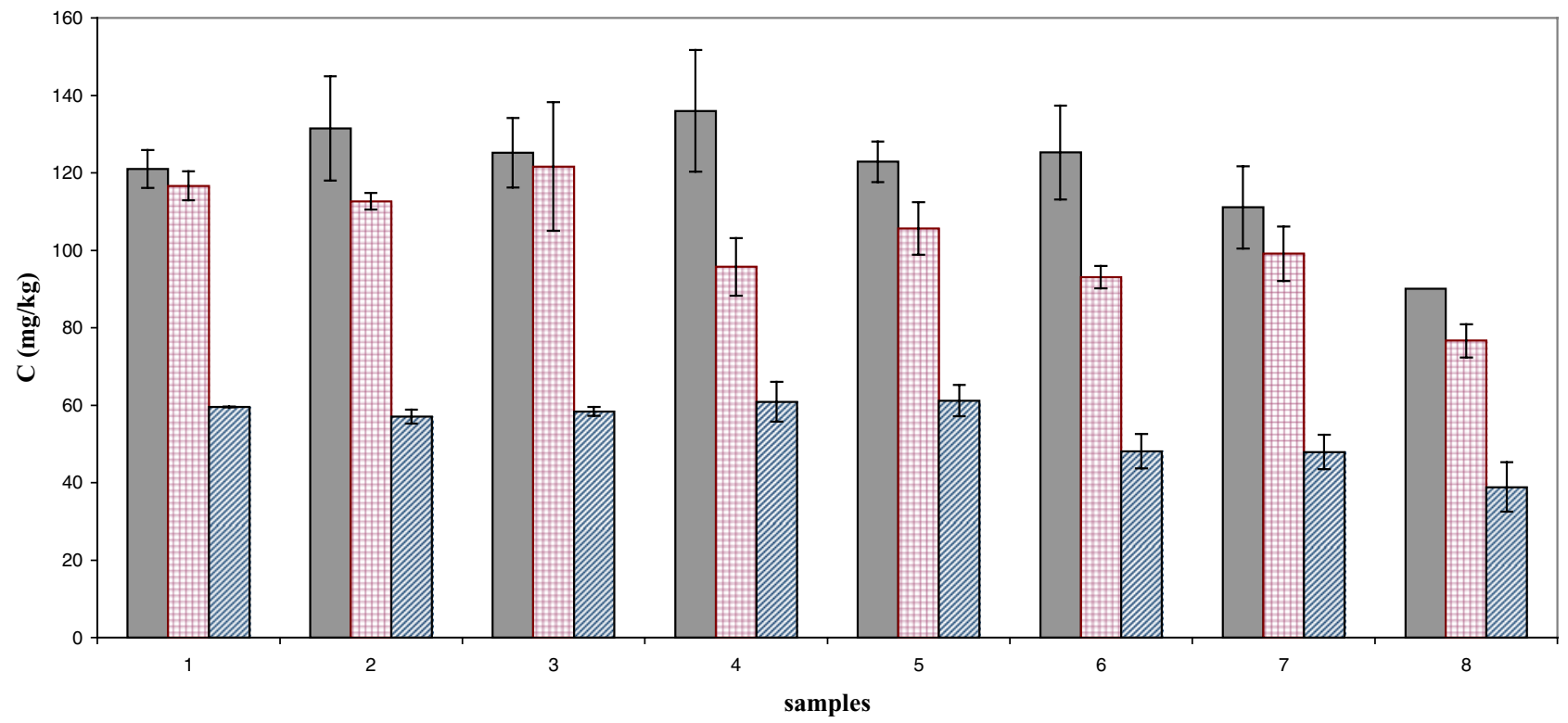

Fig. 1 Cr results on eight agricultural soil samples collected in a reference site in Italy determined by ICP-MS after acid digestion by methods A, $\mathrm{B}$, and C (grey method A; squared method B; striped method C). The uncertainty represents the standard deviation of three replicates

samples. The relative standard deviation for all elements (As, $\mathrm{Co}, \mathrm{Cr}, \mathrm{Sb}$ and $\mathrm{Zn}$ ) was less than $4 \%$. These results indicate that the differences of measurement results using different methods can be detected when the differences are higher than the residual heterogeneity in the test samples.

In the soil samples, the better precision of method $\mathrm{A}$ in comparison with method B is not confirmed. As an example, precision for As ranges from 1 to $14 \%$ (method A) and from 1 to $6 \%$ (method $\mathrm{B})$, while for $\mathrm{Cr}$ ranges from 1 to $13 \%(\operatorname{method} \mathrm{A})$ and from 2 to $16 \%(\operatorname{method} \mathrm{B})$. This seems to point to a different sample behavior of the agricultural soils and the RMs (IAEA Soil 7 and IAEA SL1), possibly due to the different matrices and different levels of homogeneity in RMs and in test samples used in this investigation.

The results for $\mathrm{As}, \mathrm{Cd}, \mathrm{Co}, \mathrm{Cr}, \mathrm{Cu}, \mathrm{Ni}, \mathrm{Pb}, \mathrm{Sb}$ and $\mathrm{Zn}$ using methods $\mathrm{A}$ and $\mathrm{B}$ on the eight agricultural soils are pooled on the basis of studies of RMs, revealing a similar behavior. The results obtained by means of methods $\mathrm{A}$ and $\mathrm{B}$ are compared with those measured after sample extraction by method $\mathrm{C}$ (Table 6). All the results are reported with their experimental standard uncertainty, with a coverage factor of 2 to yield an approximate confidence level of $95 \%$.

Analysis of variance using the ANOVA test at a confidence level of $\alpha=0.05$ was performed to assess the significance of differences among the three methods. ANOVA shows no significant differences for $\mathrm{As}, \mathrm{Cd}, \mathrm{Co}, \mathrm{Cu}, \mathrm{Ni}, \mathrm{Pb}$ and $\mathrm{Zn}$. These results suggest that for the soil analyzed the partial digestion method aqua regia leads to results equivalent to those of the total digestion methods.

For $\mathrm{Cr}$, the ANOVA test shows a statistically significant difference among the methods A-B-C, attributable to method C. As can be easily recognized from Fig. 1 and Table $6, \mathrm{Cr}$ mass fractions determined by using method $\mathrm{C}$ are lower by a factor of two than by using methods A and B. This could be due to the presence of insoluble refractory $\mathrm{Cr}$ minerals which cannot be dissolved without using HF. Similar low recoveries (23-74\%) for $\mathrm{Cr}$ using an aqua regia digestion procedure are described in the literature for river sediments and soils [28, 29].

The ICP-MS results on samples digested by using method $\mathrm{C}$ for $\mathrm{Sb}$ (Fig. 2 and Table 6) show mass fraction values about $50 \%$ lower than those obtained by using method A and B. These results could be due to a not efficient extraction of $\mathrm{Sb}$ normally bound to silicates.

A $t$-test at a confidence level of $\alpha=0.05$ between results obtained by methods A and B showed no significant difference for $\mathrm{Cr}$ and $\mathrm{Sb}$.

Comparison of ICP-MS measurements results with INAA in measuring elements in agricultural soils

Among the trace elements selected in this investigation, As, $\mathrm{Zn}, \mathrm{Co}, \mathrm{Cr}$ and $\mathrm{Sb}$ were measured by INAA as well. Table 7 reports the grand mean of As, $\mathrm{Zn}$, Co mass fraction values obtained by ICP-MS after the soil digestion with methods A, B and C, as well as the INAA analytical results for the eight agricultural soils investigated. INAA data are re- 
Sb (Methods A-B-C)

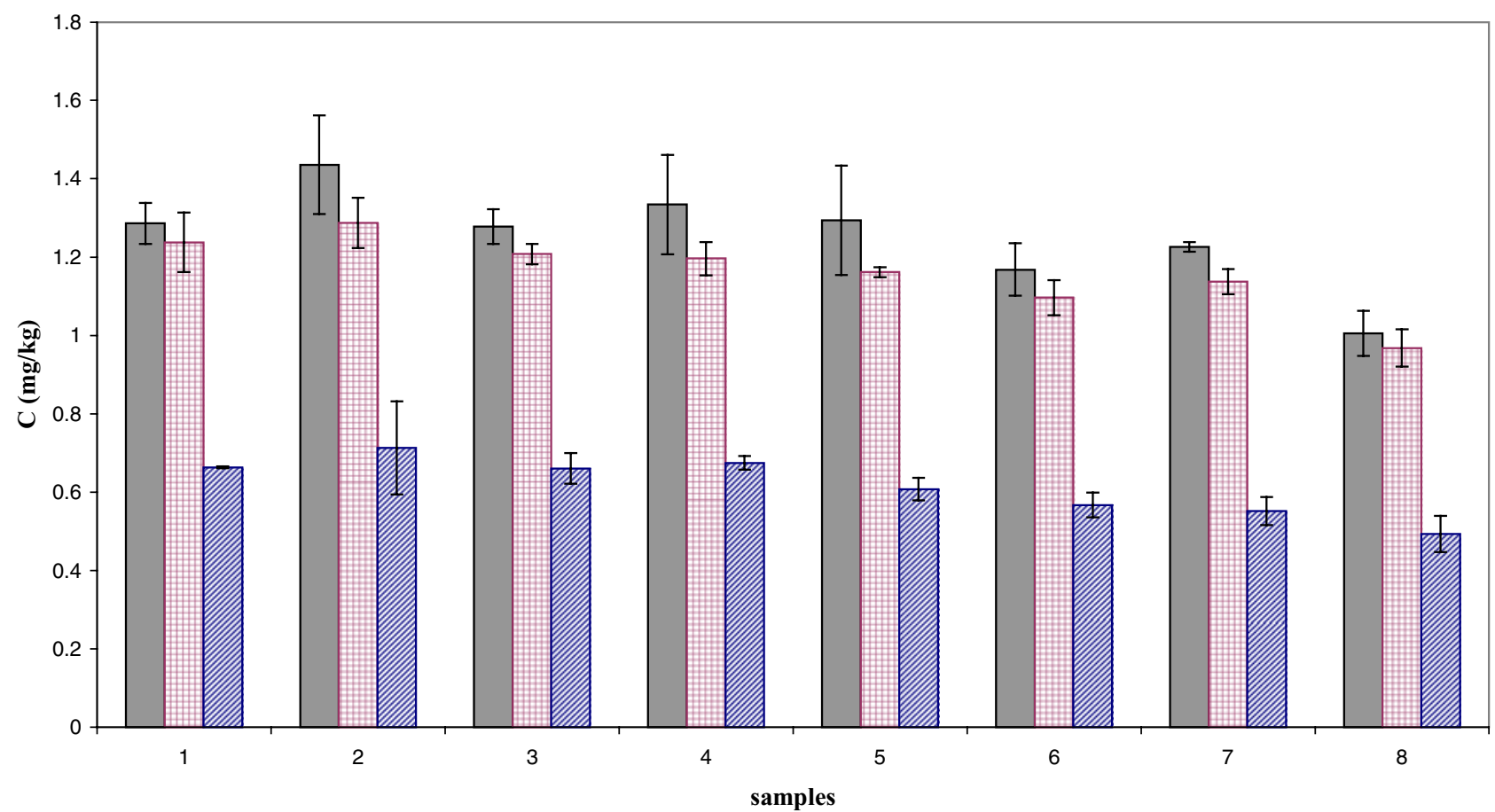

Fig. $2 \mathrm{Sb}$ results on eight agricultural soil samples collected in a reference site in Italy determined by ICP-MS after acid digestion by methods A, $\mathrm{B}$, and C (grey method A; squared method B; striped method C). The uncertainty represents the standard deviation of three replicates

ported with their standard deviation from counting statistics in gamma spectrometry. The comparison of $\mathrm{k}_{0}$-INAA results with those obtained by ICP-MS are in good agreement for all elements except for $\mathrm{Zn}$ that is slightly underestimated. This result confirms the need for future study of $\mathrm{Zn}$ measurement by ICP-MS. Looking at the results obtained after the digestion with method A, Cr mass fractions in soil are lower than $\mathrm{k}_{0}$-INAA values (Table 8 ). These results are attributable to an incomplete digestion of $\mathrm{Cr}$, bound to residual fraction as refractory mineral, even when using HF. Yang et al. [24] reported low recoveries for $\mathrm{Cr}$ in a certified reference material, HISS (sediment), using ICP-MS and closed vessel digestion with $\mathrm{HF}$ and $\mathrm{HNO}_{3}$. The authors obtained mass fraction values which were almost a factor three lower than the value found by INAA. Sb mass fraction values in ICP-MS measurements are slightly higher than INAA measurements. The presence of HF in the digestion mixture, in this case, is sufficient to completely digest silicate bound $\mathrm{Sb}$.

Table 7 ICP-MS and INAA results on agricultural soil samples collected at a reference site in Italy

\begin{tabular}{|c|c|c|c|c|c|c|}
\hline \multirow[t]{2}{*}{ Soil sample } & \multicolumn{2}{|l|}{ As $\left(\mathrm{mg} \mathrm{kg}^{-1}\right)$} & \multicolumn{2}{|l|}{$\mathrm{Zn}\left(\mathrm{mg} \mathrm{kg}^{-1}\right)$} & \multicolumn{2}{|l|}{$\mathrm{Co}\left(\mathrm{mg} \mathrm{kg}^{-1}\right)$} \\
\hline & $\begin{array}{l}\text { ICP-MS Grand mean } \\
\text { methods A, B, C* }(n=3)\end{array}$ & $\begin{array}{l}\text { INAA } \\
(n=1)\end{array}$ & $\begin{array}{l}\text { ICP-MS Grand mean } \\
\text { methods A, B, C }(n=3)\end{array}$ & $\begin{array}{l}\text { INAA } \\
(n=1)\end{array}$ & $\begin{array}{l}\text { ICP-MS Grand Mean } \\
\text { methods A, B, C }(n=3)\end{array}$ & $\begin{array}{l}\text { INAA } \\
(n=1)\end{array}$ \\
\hline 1 & $11 \pm 1$ & $11 \pm 1$ & $95 \pm 4$ & $101 \pm 8$ & $13.0 \pm 0.9$ & $13 \pm 1$ \\
\hline 2 & $11 \pm 1$ & $11 \pm 1$ & $91 \pm 12$ & $97 \pm 8$ & $12.5 \pm 0.4$ & $13 \pm 1$ \\
\hline 3 & $11.4 \pm 1.1$ & $11 \pm 1$ & $90 \pm 5$ & $99 \pm 8$ & $12.9 \pm 0.2$ & $13 \pm 1$ \\
\hline 4 & $11.5 \pm 1.4$ & $12 \pm 1$ & $88 \pm 3$ & $90 \pm 7$ & $12.1 \pm 0.3$ & $12 \pm 1$ \\
\hline 5 & $10.8 \pm 0.9$ & $10.7 \pm 0.8$ & $89 \pm 3$ & $89 \pm 7$ & $12.7 \pm 0.5$ & $12 \pm 1$ \\
\hline 6 & $9.7 \pm 0.5$ & $9.0 \pm 0.7$ & $80 \pm 5$ & $83 \pm 7$ & $10.9 \pm 0.5$ & $11 \pm 1$ \\
\hline 7 & $9.6 \pm 0.5$ & $9.5 \pm 0.8$ & $77 \pm \underline{9}$ & $85 \pm 7$ & $10.7 \pm 0.5$ & $11 \pm 1$ \\
\hline 8 & $8.4 \pm 0.5$ & $8.7 \pm 0.7$ & $68 \pm \overline{2}$ & $73 \pm 6$ & $9.1 \pm 0.4$ & $9.5 \pm 0,8$ \\
\hline
\end{tabular}

Note: Grand means of data obtained after digestion with method A, B, and C. Results are reported with their standard deviations at a confidence level of approximately $95 \%$ ( $n=$ number of independent replicates).

Methods $\mathrm{A}, \mathrm{B}, \mathrm{C}^{*}=$ grand mean of the ICP-MS results after digestion with method $\mathrm{A}\left(\mathrm{HNO}_{3}+\mathrm{HF}\right), \mathrm{B}\left(\mathrm{HCl}+\mathrm{HNO}{ }_{3}+\mathrm{HF}\right)$ and $\mathrm{C}$ $\left(\mathrm{HCl}+\mathrm{HNO}_{3}+\mathrm{H}_{2} \mathrm{O}_{2}\right)$. 
Table $8 \mathrm{Cr}$ and $\mathrm{Sb}$ mass fractions on agricultural soil samples collected in a reference site in Italy

\begin{tabular}{|c|c|c|c|c|}
\hline \multirow[t]{2}{*}{ Soil sample } & \multicolumn{2}{|l|}{$\mathrm{Cr}\left(\mathrm{mg} \mathrm{kg}^{-1}\right)$} & \multicolumn{2}{|l|}{$\mathrm{Sb}\left(\mathrm{mg} \mathrm{kg}^{-1}\right)$} \\
\hline & $\begin{array}{l}\text { ICP-MS Method A* } \\
(n=3)\end{array}$ & INAA $(n=1)$ & $\begin{array}{l}\text { ICP-MS Method A } \\
(n=3)\end{array}$ & $\begin{array}{l}\text { INAA } \\
(n=1)\end{array}$ \\
\hline 1 & $121 \pm 10$ & $223 \pm 19$ & $1.3 \pm 0.1$ & $1.2 \pm 0.1$ \\
\hline 2 & $132 \pm 27$ & $260 \pm 21$ & $1.4 \pm 0.3$ & $1.2 \pm 0.1$ \\
\hline 3 & $125 \pm 18$ & $215 \pm 19$ & $1.28 \pm 0.09$ & $1.3 \pm 0.1$ \\
\hline 4 & $136 \pm 31$ & $215 \pm 19$ & $1.3 \pm 0.3$ & $1.3 \pm 0.1$ \\
\hline 5 & $123 \pm 10$ & $219 \pm 19$ & $1.3 \pm 0.3$ & $1.2 \pm 0.1$ \\
\hline 6 & $125 \pm 24$ & $234 \pm 21$ & $1.2 \pm 0.1$ & $1.1 \pm 0.1$ \\
\hline 7 & $111 \pm 21$ & $250 \pm 21$ & $1.23 \pm 0.02$ & $1.1 \pm 0.1$ \\
\hline 8 & $90 \pm 2$ & $224 \pm 19$ & $1.01 \pm 0.08$ & $1.0 \pm 0.1$ \\
\hline
\end{tabular}

Note: Comparison between the results obtained with method A (a) and ICP-MS and INAA results (b). Results are reported with their standard deviations at a confidence level of about $95 \%$ ( $n=$ number of independent replicates).

Method $\mathrm{A}^{*}=\mathrm{HNO}_{3}+\mathrm{HF}$.

\section{Conclusions}

For methods $\mathrm{A}$ and $\mathrm{B}$, results for $\mathrm{Co}, \mathrm{Ni}, \mathrm{Cu}, \mathrm{As}, \mathrm{Sb}$ and $\mathrm{Cd}$ were found in a very good agreement, while for method $\mathrm{C}$ the results for, $\mathrm{Cu}, \mathrm{Cd}$ and $\mathrm{Pb}$ corresponded well with the certified values of the selected RMs.

Both methods A and B generally showed a good repeatability standard deviation. The higher precision of method A is found only in the case of the RMs and not for the real soil samples analyzed. Concerning method $\mathrm{C}$, the results on LGC-6187 show higher repeatability than those on BCR141R.

Modified digestion conditions, occurring in method C, in terms of energy input of microwave, resulted in positively biased values for $\mathrm{Cr}$ element for both CRMs certified for aqua regia soluble mass fraction (LGC-6187 and BCR141R). $\mathrm{Cd}, \mathrm{Pb}$ and $\mathrm{Cu}$ mass fraction values are in agreement with the certified values in both CRMs. $\mathrm{Zn}$ results are generally negatively biased for all methods. $\mathrm{Zn}$ is generally brought into solution, thus the ICP-MS procedure used in this study needs further investigation.

ANOVA was performed on the ICP-MS results obtained after the application of the three digestion methods on eight agricultural soil samples, collected in one test area. The only significant differences are related to $\mathrm{Cr}$ and $\mathrm{Sb}$ results obtained after extraction with method $\mathrm{C}$ (modified aqua regia). This could be due to the presence in the soil of insoluble $\mathrm{Cr}$ minerals and $\mathrm{Sb}$ bound to silicates.

$\mathrm{k}_{0}$-INAA analytical results of the soil samples were compared with ICP-MS measurements on the same test samples. The results of As and Co are in good agreement regardless which of the three digestion methods is used. In this case, the procedures used do not affect the final analytical results.

Cr results, even if obtained with "total" digestion method with the best recovery (method A), are lower by a factor of 2 than the INAA results. Sb after digestion with $\mathrm{HNO}_{3}+\mathrm{HF}$ is in good agreement with INAA results.
In conclusion, the results reported in this paper highlight that the digestion procedure is an essential part of the definition of the measurement procedure in environmental analysis.

Acknowledgements The authors would like to thank Dr. Ales Fajgelj from IAEA, Agency's Laboratories Seibersdorf, for his valuable review and suggestions and Prof. Paul De Bievre for his patience in reviewing this paper.

\section{References}

1. Burau RE (1982) Lead. Page AL et al (eds) Methods of soil analysis, Part 2, chemical and microbiological properties, 2nd edn. Agron Monogr, vol. 9, ASA and SSSA, Madison, WI, USA, pp 347-366

2. Hseu Z, Chen Z, Tsai C, Tsui Cheng S, Liu C, Lin H (2002) Digestion methods for total heavy metals in sediments and soils. Water Air Soil Pollut 141:189-205

3. Reisenaur HM (1982) Chromium. Page AL et al (eds) Methods of soil analysis, Part 2, chemical and microbiological properties, 2nd edn. Agron Monogr, vol 9, ASA and SSSA, Madison, WI, USA, pp 337-346

4. Chen M, Lena QM (2001) Comparison of three aqua regia digestion methods for twenty Florida soils. Soil Sci Soc Am J 65:491499

5. Quevauviller P, Imbert J, Olle M (1993) Evaluation of the use of microwave oven system for digestion of environmental samples. Mikrochim Acta 112:147-154

6. Smith FE, Arsenault EA (1996) Microwave-assisted sample preparation in analytical chemistry. Talanta 43:1207-1268

7. USEPA 3050B (1996) Acid digestion of sediments, sludges and soils. Environmental Protection Agency, Washington, DC

8. ISO 11466 (1995) Soil quality: extraction of trace elements soluble in aqua regia. ISO, Geneva, Switzerland

9. Vercoutere K, Fortunati U, Muntau H, Griepink B, Maier EA (1995) The certified reference materials CRM 142 R light sandy soil, CRM 143 R sewage sludge amended soil and CRM 145 R sewage sludge for quality control in monitoring environmental and soil pollution. Fres J Anal Chem 352:197-202

10. Ministerial Decree, 13 Settembre 1999 "Approvazione dei metodi ufficiali di analisi chimica del suolo", S.O. Gazzetta Ufficiale n. 248, 21 October 1999 
11. EN 13656 (2002) Characterization of waste: microwave-assisted digestion with hydrofluoric (HF), nitric (HNO3), and hydrochloric $(\mathrm{HCl})$ acid mixture for subsequent determination of elements. EN Standards. http://en-standards.standardsdirect.org/

12. Nadkarni RA (1984) Application of microwave oven sample dissolution in analysis. Anal Chem 56:2233-2237

13. Ammons JT, Essington ME, Lewis RJ, Gallagher AO, Lessman GM (1995) An application of a modified microwave total dissolution technique for soils. Commun Soil Sci Plant Anal 26:831-842

14. Smith R (1994) Handbook of environmental analysis, 2nd edn. Genium Publishing Corp., Schenectady, NY

15. Mendoza CA, Cortes G, Munoz D (1996) Heavy metal pollution in soils and sediments of rural developing district 063, Mexico. Environ Toxicol Water Qual 11:327-333

16. de Zorzi P, Belli M, Barbizzi S, Menegon S, Deluisa A (2002) A practical approach for assessment of sampling uncertainty. Accred Qual Assur 5(7):182-188

17. Barbizzi S, de Zorzi P, Belli M, Pati A, Sansone U, Stellato L, Barbina M, Delusa A, Menegon S, Coletti V (2004) Characterisation of reference site for quantifying uncertainties related to soil sampling. Environ Pollut 127:131-135

18. Jaćimović R, Lazaru A, Mihajlović D, Ilić R, Stafilov T (2002) Determination of major and trace elements in some minerals by $\mathrm{k} 0$ instrumental neutron activation analysis. J Radioanal Nucl Chem 253:427-434

19. de Zorzi P, Barbizzi S, Belli M, Ciceri G, Fajgelj A, Moore D, Sansone U, Van Der Perk M (2005) Terminology in soil sampling (IUPAC Recommendation 2005). Pure Appl Chem 5(77):827-841
20. ISO 3534-1 (1993) Statistics-vocabulary and symbols. ISO, Geneva, Switzerland

21. APAT (2005) Interconfronto IC001. Sedimenti lacustri 49/2005. ISBN 88-448-0142-6 APAT, Rome, Italy

22. APAT (2006) Final report proficiency test APAT-IC002. Determination of metals in compost 67/2006. ISBN 88-448-0178-7 APAT, Rome, Italy

23. Kelly WR, Murphy KE, Becker DA, Mann JL (2003) Determination of $\mathrm{Cr}$ in certified reference material HISS-1, marine sediment, by cold plasma isotope dilution ICP-MS and INAA: comparison of microwave versus closed (Carius) tube digestion. J Anal At Spectrom 18:166-169

24. Yang J, Lam JW, Sturgeon RE, McLaren JW (1998) Decomposition of marine sediments for quantitative recovery of chromium and inductively coupled plasma mass spectrometric analysis. J Anal At Spectrom 13:1245-1248

25. IAEA/RL/64 Report on the intercomparison run IAEA-SL-1. Trace elements in lake sediments. IAEA, Vienna, Austria

26. IAEA/RL/112 (1984) Report on the intercomparison run IAEASOIL-7. Trace elements in soil. IAEA, Vienna, Austria

27. ISO Guide 33 (2000) Uses of certified reference international. ISO, Geneva, Switzerland

28. Heydorn K, Damsgaard E (1995) Indirect determination of soluble trace elements in certified reference materials by neutron activation analysis. Mikrochim Acta 119:297-304

29. Liu J, Sturgeon RE, Boyko VJ, Willie SN (1996) Determination of total chromium in marine sediment reference material BCSS-1. Fres J Anal Chem 356:416-419 